\title{
Bibliography
}

\section{Literary Sources}

Amarakośa (with the commentary Tịkāsarvasva of Sarvānanda): Gaṇapati Sâstrî 1914-17

Arthaśāstra ascribed to Kauțilya: Kangle 1960

Aștāâdhyāyī of Pāṇini: R. N. Sharma 2002-03

Baudhāyana śrautasūtra: Caland 1904-1917

Bṛhatsam hitā of Varāhamihira with the commentary of Utpala:

Tripāțhī 1968

Note that Utpala's version of the text (as well as Varāhamihira's own "table of contents" given in Bṛhatsaṃitā 106.5) lacks Chapter 38 of other redactions (Pingree 1981, 73 n. 37). Hence chapter numbers 38 onward in Utpala's text correspond to the next higher number in editions without Utpala's commentary, such as Kern (1865).

Buddhacarita of Aśvaghoșa: Johnston 1936

Harivamśa: constituted text in Vaidya 1969, appendix in Vaidya 1971

Harșacarita of Bāṇa: Führer 1909

Kāvyādarśa of Daṇ̣̣in: Raddi Shastri 1938

Mahābhārata: digital edition Mahabharata Online http://gretil. sub.uni-goettingen.de/gretil/1_sanskr/2_epic/mbh/sas/ mahabharata.htm ultimately based on the critical edition of the Bhandarkar Oriental Research Institute

Mālatīmādhava of Bhavabhūti: Coulson 1989

Meghadūta of Kālidāsa: De and Raghavan 1970

Mudrārākșasa of Viśākhadatta: Hillebrandt 1912

Narasiṃhapurāṇa: Jena 1987

Pādatāọitaka of Śyāmilaka: Dezső and Vasudeva 2009, 3-161

Raghuvamśa of Kālidāsa (with the commentary of Vallabhadeva): Goodall and Isaacson 2003

Rāmāyaṇa ascribed to Vālmīki: digital edition in GRETIL, http:// gretil.sub.uni-goettingen.de/gret_utf.htm\#Ram, originally input by Muneo Tokunaga and revised by John Smith

Revākhaṇ̣̂a (assigned to the Vāyupurāna or the Skandapurāna): digital edition in GRETIL, http://gretil.sub.uni-goettingen.de/ gretil/1_sanskr/3_purana/skprevku.htm, input by Jürgen Neuß

Samyuttanikāya: digital edition at http://www.tipitaka.de/roman/ tipitaka\%20(mula)/suttapitaka/samyuttanikaya/index.html

Sīmavisodhanīpāțha: digital edition at http://www.tipitaka.de/ roman/anya/pakinnaka-gantha-sangaho/simavisodhanipatha/ index.html

Early Skandapurāṇa: Bakker, Bisschop, and Yokochi 2014

\section{Epigraphic Sources}

Abhona plates of Śankkaragana: Pathak 1908a

Allahabad pillar inscription of Samudragupta: Siddham IN00001; CII3 1; CII3rev 1, SI III.2

Badoh-Pathari Saptamātr panel inscription: Siddham IN00225; Balogh 2019

Badwa yūpa inscriptions: Siddham IN00135 to IN00138; Altekar 1936 and Altekar 1938

Barnala yūpa inscriptions: Altekar 1942

Bijayagadh yūpa inscription of Viṣnuvardhana: Siddham IN00108; CII3 59
Bodhgaya image inscription of Mahānāman: Siddham IN00120 CII3 72

Gwalior inscription of Mihirakula: Siddham IN00100; CII3 37; SI III.57 Junagadh rock inscription of the time of Skandagupta: Siddham IN00032; CII3 14; CII3rev 28; SI III.25

Karamdanda linga inscription: Siddham IN00025; CII3rev 21; SI III.17 Mehrauli iron pillar inscription of Candra: Siddham IN00015; CIII3 32; CII3rev 12; SI III.14

Nandsa yūpa inscriptions: Siddham IN00216 to IN00219; Altekar 1948 Nasik inscription of Ușavadāta: Senart 1906, 78-81 (No. 10)

Nāsik inscription No. 26: Senart 1906, 95 (No. 26)

\section{References}

Acharya, G. V. 1939. 'Report of the Archaeological Section for the Year April 1938-March 1939'. Prince of Wales Museum of Western India Report 1938-39: 10-14.

Agrawal, Ashvini. 1989. Rise and Fall of the Imperial Guptas. Delhi: Motilal Banarsidass.

Agrawal, Ashvini. 2002. 'Identification of Ādityavardhana of the Mandsaur Inscription of Mahārāja Gauri'. Research Bulletin of the Vishveshvaranand Vedic Research Institute 1: 148-54.

Agrawal, Jagannath. 1939. 'Nagaṇā in the Mandasor Inscription of the Mālava Year 529'. Journal of Indian History 18: 118-19.

Agrawal, Jagannath. 1941. 'Epigraphic Notes'. In Proceedings of the Indian History Congress. Fourth Session: Lahore, 1940, 58-61. Lahore: Indian History Congress Association.

Agrawal, Jagannath. 1946a. 'Govindagupta, a New Gupta Emperor'. Indian Historical Quarterly 22: 286-90.

Agrawal, Jagannath. 1946b. 'Govindagupta, a New Gupta Emperor'. In Proceedings of the Indian History Congress. Ninth Session: Patna University, Patna, 78-82. Allahabad: Indian History Congress.

Agrawal, Jagannath. 1986a. 'A Study of Some Verses of the Mandasor Stone Inscription Dated Malava Year 529'. Journal of the Royal Asiatic Society 118: 53-58. Also published as 1986b, 79-86.

Agrawal, Jagannath. 1986b. Researches in Indian Epigraphy and Numismatics. Delhi: Sundeep Prakashan.

Agrawal, Jagannath. 1989. 'New Light on Yasodharman Visnuvardhana and the Hunas'. In Ajaya-Sri. Recent Studies in Indology. Prof. Ajay Mitra Shastri Felicitation Volume, edited by Devendra Handa, 97-100. Delhi: Sundeep Prakashan.

Agrawal, Jagannath. 1990. 'Two Verses of the Risthal Stone Slab Inscription'. In Indian History and Epigraphy. Dr. G. S. Gai Felicitation Volume, edited by K. V. Ramesh, S. P. Tewari, and M. J. Sharma, 129-30. Delhi: Agam Kala Prakashan. Also published as 1986b, 92-94.

Agrawala, Prithvi Kumar. 1983. Imperial Gupta Epigraphs (गुप्ताधिराजलेखमण्डल). Ancient Indian Epigraphical Sources (प्रत्नाभिलेखसंहिता), X.1. Varanasi: Books Asia.

Agrawala, Vasudev Sharan. 1950. 'A New Gupta Temple at Darrā in Malwa'. Journal of the Uttar Pradesh Historical Society 23: 196-97. 
Allan, John. 1914. Catalogue Of The Coins Of The Gupta Dynasties. London: British Museum.

Altekar, Anant Sadashiv. 1936. 'Three Maukhari Inscriptions on Yupas: Krita Year 295’. Epigraphia Indica 23: 42-52.

Altekar, Anant Sadashiv. 1938. 'Fourth Maukhari Yupa Inscription from Badva'. Epigraphia Indica 24: 251-53.

Altekar, Anant Sadashiv. 1942. 'Two Yupa Inscriptions from Barnala: Krita Years 284 and 335'. Epigraphia Indica 26: 118-23.

Altekar, Anant Sadashiv. 1948. 'Nandsa Yupa Inscriptions'. Epigraphia Indica 27: 252-67.

ARASI. Annual Report of the Archaeological Survey of India. Calcutta/Delhi: Archaeological Survey of India.

ARIE. Annual Report on Indian Epigraphy. Calcutta/New Delhi: Archaeological Survey of India.

Bakker, Hans T. 2006. 'A Theatre of Broken Dreams'. In Interrogating History. Essays for Hermann Kulke, edited by Martin Brandtner and Shishir Kumar Panda, 165-87. New Delhi: Manohar.

Bakker, Hans T. 2014. The World of the Skandapurāna: Northern India in the Sixth and Seventh Centuries. Groningen Oriental Studies Supplement. Leiden: Brill.

Bakker, Hans T. 2017. Monuments of Hope, Gloom, and Glory in the Age of the Hunnic Wars. 50 Years That Changed India (484-534). J. Gonda Lectures 24. Amsterdam: J. Gonda Fund Foundation of the KNAW.

Bakker, Hans T. 2018. 'No Texts without Archaeology - No Archaeology without Texts'. Unpublished paper presented at the 24th Conference of the European Association for South Asian Archaeology and Art, Naples.

Bakker, Hans T. forthcoming. 'Sanskrit Epigraphical Sources'. In Hunnic Peoples in Central and South Asia: A Sourcebook, edited by Dániel Balogh.

Bakker, Hans T., and Peter C. Bisschop. 2016. 'The Quest for the Pāśupata Weapon: The Gateway of the Mahādeva Temple at Madhyamikā (Nagarī)'. Indo-Iranian Journal 59 (3): 217-58.

Balogh, Dániel. 2013. 'Tracking a Devil in a Textual Maze'. Acta Orientalia Academiae Scientiarum Hungaricae 66 (3): 247-65.

Balogh, Dániel. 2015. 'A Textual and Intertextual Study of the Mudrārākșasa'. PhD Thesis, Budapest: Eötvös Loránd University.

Balogh, Dániel. 2017. 'The Abominable Yati - Or, An Intriguing Relic of the Prehistory of Sanskrit Verse'. In Pușpikā: Tracing Ancient India, through Texts and Traditions. Contributions to Current Research in Indology. Volume 4, Proceedings of the Seventh International Indology Graduate Research Symposium (Leiden, 2015), edited by Lucas den Boer and Daniele Cuneo, 14-32. Oxford, Philadelphia: Oxbow Books.

Balogh, Dániel. 2019. 'The Badoh-Pathari Saptamātṛ Panel Inscription'. Indo-Iranian Journal 62: 191-226.

Balogh, Dániel, ed. forthcoming. Hunnic Peoples in Central and South Asia: Sources for their Origin and History.

Banerji, Rakhal Das. 1919. 'The Chronology of the Late Imperial Guptas'. Annals of the Bhandarkar Oriental Research Institute 1: $67-80$

Basham, A. L. 1983. 'The Mandasor Inscription of the Silk-Weavers'. In Essays on Gupta Culture, edited by Bardwell L. Smith, 93-105. Delhi, Varanasi, Patna: Motilal Banarsidass.

Basham, A. L. 1984. 'Notes on the Origins of Śāktism and Tantrism'. In Religion and Society in Ancient India. Sudhakar Chattopadhyaya Commemoration Volume, edited by Pranabananda Jash, 148-54. Calcutta: Roy \& Chowdhury.
Bhandarkar, Devadatta Ramakrishna. 1908. 'Vasantgadh Inscription of Varmalata; [Vikrama] Samvat 682'. Epigraphia Indica 9: 187-92.

Bhandarkar, Devadatta Ramakrishna. 1913. 'Epigraphic Notes and Questions XVIII. Mandasor Inscription of Naravarman'. The Indian Antiquary 42: 161-63.

Bhandarkar, Devadatta Ramakrishna. 1917. 'Vikrama Era’. In Commemorative Essays Presented to Sir Ramkrishna Gopal Bhandarkar, 187-94. Poona: Bhandarkar Oriental Research Institute.

Bhandarkar, Devadatta Ramakrishna. 1920. The Archaeological Remains and Excavations at Nagari. Memoirs of the Archaeological Survey of India 4. Calcutta: Superintendent of Government Printing.

Bhandarkar, Devadatta Ramakrishna. 1929. A List of the Inscriptions of Northern India in Brahmi and Its Derivative Scripts, from about 200 A. C. (Appendix to Epigraphia Indica Volumes XIX to XXIII). Calcutta: University of Calcutta.

Bhandarkar, Ramakrishna Gopal. 1889. 'The Epoch of the Gupta Era'. Journal of the Bombay Branch of the Royal Asiatic Society 17/2: 80-98.

Bhandarkar, Ramakrishna Gopal 1902. 'A Peep into the Early History of India from the Foundation of the Maurya Dynasty to the Fall of the Imperial Gupta Dynasty (B. C. 322-circa 500 A. D.).' Journal of the Bombay Branch of the Royal Asiatic Society 20: 356-408.

Bhandarkar, Ramakrishna Gopal 1913. 'Note of(sic!) the Mandasor Inscription of Naravarman'. The Indian Antiquary 42: 199-200.

Bhattacharyya, Pranab Kumar. 1977. Historical Geography of Madhya Pradesh from Early Records. Motilal Banarsidass.

Bhide, H. B. 1921. 'Gangdhar Inscription of Visvavarman (Fleet's Gupta Inscriptions, No. 17)'. Journal of the Bihar and Orissa Research Society 7: 33-35.

Bisschop, Peter. 2010. 'Śaivism in the Gupta-Vākāțaka Age'. Journal of the Royal Asiatic Society 20 (4): 477-88.

Böhtlingk, Otto von, and Rudolf von Roth. 1855-1875. SanskritWörterbuch. 7 vols. St. Petersburg: Kaiserlichen Akademie der Wissenschaften.

Bose, Sushil K. 1938. 'Studies in Gupta Paleography'. Indian Culture 4: 181-88, 325-46.

Buddha Prakash. 1965. Aspects of Indian History and Civilization. Agra: Shiva Lal Agarwala.

Bühler, Johann Georg. 1876. 'Grants from Valabhî'. The Indian Antiquary 5: 204-12.

Bühler, Johann Georg. 1890. 'Die indische Inschriften und das Alter der indischen Kunstpoesie'. Sitzungsberichte der kaiserlichen Akademie der Wissenschaften in Wien, Philosophisch-historische Klasse 122: XI/1-97.

Bühler, Johann Georg. 1896. Indische Palaeographie von circa 350 A. Chr. - circa 1300 P. Chr. Strassburg: Karl J. Trübner.

Bühler, Johann Georg. 1904. Indian Paleography from about B. C. 350 to about A. D. 1300 by G. Bühler (Appendix to The Indian Antiquary, Vol. XXXIII). Edited by John Faithfull Fleet. Bombay.

Bühler, Johann Georg. 1913. 'The Indian Inscriptions and the Antiquity of Indian Artificial Poetry'. Translated by V. S. Ghate. The Indian Antiquary 42: 29-37, 137-48, 172-79, 188-93, 230-34, 243-49.

Caland, Willem. 1904-1917. The Baudhāyana Śrauta Sūtra Belonging to the Taittirīya Samphitā. 4 vols. Calcutta: Asiatic Society. 
Casile, Anne. 2007. 'The Archaeological Remains of Rāmgarh Hill: A Report'. In The Temple in South Asia, 29-48. London: British Association for South Asian Studies.

Cecil, Elizabeth A. 2016. 'Mapping the Pāśupata Landscape: The Skandapurāna, Lakulīśa, and the Śaiva Imaginary in Early Medieval North India (6th-10th Century CE)'. PhD Thesis, Providence, Rhode Island: Brown University.

Cecil, Elizabeth A. 2018a. 'Seeing Double in Daśapura: Yaśodharman's Twin Columns as Monuments to Competition and Camaraderie'. Unpublished paper presented at the 228th Meeting of the American Oriental Society, Pittsburgh, PA.

Cecil, Elizabeth A. 2018b. 'Columns in Context: Monumental Inscriptions and Landscapes of Memory in Early India'. Unpublished paper presented at the 17th World Sanskrit Conference, Vancouver.

Cecil, Elizabeth A., and Peter C. Bisschop. 2019. 'Venerable Monuments and Landscapes of Memory in Early India'. History of Religions 58 (4): 355-403.

Chakravarti, S. N. 1942. 'Bihar Kotra Inscription of Naravarman's Time; [Malava] Year 474'. Epigraphia Indica 26: 130-32.

Coulson, Michael. 1989. A Critical Edition of the Mālatīmādhava. Revised by Roderick Sinclair. Delhi: Oxford University Press.

Cunningham, Alexander. 1871. Four Reports Made during the Years 1862-63-64-65, Volume II. Archaeological Survey of India Reports 2. Calcutta: Superintendent of Government Printing.

Dani, Ahmad Hasan. 1963. Indian Palaeography. Oxford: Clarendon Press.

De, Sushil Kumar, and V. Raghavan, eds. 1970. The Megha-Dūta of Kālidāsa. 2nd revised edition. New Delhi: Sahitya Akademi.

Dehejia, Vidya. 1986. 'Brick Temples: Origins and Development'. In From Indian Earth: 4,000 Years of Terracotta Art, edited by Amy G. Poster, 43-56. New York: The Brooklyn Museum.

Dehejia, Vidya, and Peter Rockwell. 2016. The Unfinished: Stone Carvers at Work on the Indian Subcontinent. New Delhi: Lustre Press, Roli Books.

Dey, Nando Lal. 1979. The Geographical Dictionary of Ancient and Mediaeval India. 2nd ed. New Delhi: Cosmo Publications.

Dezső, Csaba, and Somadeva Vasudeva. 2009. The Quartet of Causeries. New York: NYU Press \& JJC Foundation.

Diskalkar, D. B. 1925. Selections From Sanskrit Inscriptions. Part II: Notes and Translation. Rajkot: Aryabhushan Press.

Diskalkar, D. B. 1926. 'Epigraphic Notes and Questions'. Journal of the Bombay Branch of the Royal Asiatic Society, New Series NS 2: 176-83.

Durgâprasâd, and Kâŝînâth Pâṇụurang Parab, eds. 1892. The Prâchîna-Lekha-Mâlâ or A Collection of Ancient Historical Records. Vol. I. Kâvyamâlâ 34. Bombay: Nirnay Sagar Press.

Edgerton, Franklin. 1953. Buddhist Hybrid Sanskrit Grammar and Dictionary. 2 vols. New Haven: Yale University Press.

Fergusson, James, and James Burgess. 1880. The Cave Temples of India. London: W. H. Allen \& Co; Trübner \& Co; E. Stanford; W. Griggs.

Ferrier, Cédric, and Judit Törzsök. 2008. 'Meditating on the King's Feet? Some Remarks on the Expression Pādānudhyāta'. Indo-Iranian Journal 51: 93-113.

Fleet, John Faithfull. 1878. 'Sanskrit and Old Canarese Inscriptions No. 40'. The Indian Antiquary 7: 161-62.

Fleet, John Faithfull. 1886a. 'Sanskrit and Old-Kanarese Inscriptions No. 162. Mandasor Inscription of Kumaragupta and
Bandhuvarman: The Malava Years 493 and 529'. The Indian Antiquary 15: 194-201.

Fleet, John Faithfull. 1886b. 'Sanskrit and Old-Kanarese Inscriptions No. 163. Mandasor Inscription of Yasodharman and Vishnuvardhana: The Malava Year 589'. The Indian Antiquary 15: 222-28.

Fleet, John Faithfull. 1886c. 'Sanskrit and Old-Kanarese Inscriptions No. 164. Mandasor Pillar Inscription of Yasodharman'. The Indian Antiquary 15: 253-57.

Fleet, John Faithfull. 1886d. 'Sanskrit and Old-Kanarese Inscriptions No. 165. Mandasor Duplicate Pillar Inscription of Yasodharman'. The Indian Antiquary 15: 257-58.

Fleet, John Faithfull. 1888. Inscriptions of the Early Gupta Kings and Their Successors. Corpus Inscriptionum Indicarum, III. Calcutta: Superintendent of Government Printing.

Fleet, John Faithfull. 1889. 'Miscellanea: Corpus Inscriptionum Indicarum Vol. III'. The Indian Antiquary 18: 219-21.

Fleet, John Faithfull. 1890a. 'Sanskrit and Old Kanarese Inscriptions. No. 185. Mahakuta Pillar Inscription of Mangalesa'. The Indian Antiquary 19: 7-20.

Fleet, John Faithfull. 1890b. 'The Bhitari Seal of Kumaragupta II'. The Indian Antiquary 19: 224-28.

Fleet, John Faithfull, and Devadatta Ramakrishna Bhandarkar. 1981. Inscriptions of the Early Gupta Kings (Revised Edition). Edited by Bahadur Chand Chhabra and Govind Swamirao Gai. Corpus Inscriptionum Indicarum, III rev. New Delhi: Archaeological Survey of India.

Führer, Alois Anton. 1909. Bânabhatța's Biography of King Harshavardhana of Sthânvîśvara with Śankara's Commentary, Sanketa. Bombay Sanskrit and Prakrit Series 66. Bombay: Government Central Press.

Gai, Govind Swamirao. 1990a. Some Select Inscriptions. Delhi: Agam Kala Prakashan.

Gai, Gowind Swamirao. 1990b. 'On Sri and Srih'. Journal of the Epigraphical Society of India (Bharatiya Purabhilekha Patrika) 16: 87-89.

Gaṇapati Sâstrî, T. 1914-1917. The Nâmalingânusâsana of Amarasimha with the Two Commentaries, Amarakosodghâtana of Kshîrasvāmin and Tîkâsarvasva of VandyaghatîyaSarvânanda. 4 vols. Trivandrum Sanskrit Series 38, 43, 51, 52. Trivandrum: Travancore Government Press.

Garde, M. B. 1926. Annual Report of the Archaeological Department, Gwalior State for Samvat 1982, Year 1925-26. Gwalior: Alijah Darbar Press.

Garde, M. B. 1934. Archaeology In Gwalior. 2nd ed. Gwalior: Alijah Darbar Press.

Garde, M. B. 1938. Annual Report of the Archaeological Department, Gwalior State for Samvat 1991, Year 1934-35. Gwalior: Alijah Darbar Press.

Garde, M. B. 1948. 'Mandasor Inscription of Malava Samvat 524'. Epigraphia Indica 27: 12-18.

Ghosh, A. 1978. 'Caesura in Pṛthvī Metre'. Annals of the Bhandarkar Oriental Research Institute 58/59: 627-34.

Goodall, Dominic. 2018. 'Rudragaṇikās: Courtesans in Śiva's Temple? Some Hitherto Neglected Sanskrit Sources'. Cracow Indological Studies 20: 91-143.

Goodall, Dominic, and H. Isaacson. 2003. The Raghupañcikā of Vallabhadeva: Being the Earliest Commentary on the Raghuvaṃśa of Kālidāsa. Groningen: E. Forsten. 
Goyal, Śrīrām. 1967. A History of the Imperial Guptas. Allahabad: Central Book Depot.

Goyal, Śrīrām. 1993. गुप्तकालीन अभिलेख (Inscriptions of the Gupta Age). Jodhpur: Kusumanjali Prakashan.

Goyal, Śrīrām. 2005. Ancient Indian Inscriptions: Recent Finds and New Interpretations. Jodhpur: Kusumanjali Book World.

Greaves, Laxshmi. 2017. 'A Report on a Recently Discovered Ruined Gupta Temple at Khanderia, Bundi District, Rajasthan'. Indian Historical Review 44: 313-26.

Gupta, Parmeshwari Lal. 1974. The Imperial Guptas. Varanasi: Vishwavidyalaya Prakashan.

Handa, Devendra. 2014. 'A Copper Ring of the Aulikara King Naravarman'. History Today, Journal of History and Historical Archaeology 15: 147-48.

Handa, Devendra. 2016. 'Fresh Light on the Aulikaras'. Numismatic Digest, Journal of Indian Numismatic, Historical and Cultural Research Foundation 40: 78-85.

Harle, J. C. 1970. 'An Early Indian Hero-Stone and a Possible Western Source'. Journal of the Royal Asiatic Society 102 (2): 159-64.

Harmatta, János. 1969. 'Late Bactrian Inscriptions'. Acta antiqua Academiae Scientiarum Hungaricae 17: 297-432.

Harper, Katherine Anne. 1989. The Iconography of the Saptamatrikas: Seven Hindu Goddesses of Spiritual Transformation. Lewiston, NY: E. Mellen Press.

Hatley, Shaman. 2012. 'From Mātṛ to Yoginī: Continuity and Transformation in the South Asian Cults of the Mother Goddesses'. In Transformations and Transfer of Tantra in Asia and Beyond, edited by István Keul, 99-129. Berlin: De Gruyter.

Hillebrandt, Alfred, ed. 1912. Mudrārākșasa by Višākhadatta Edited from MSS and Provided with an Index of All Prākrit Words. Breslau: M\&H Marcus.

Hoernle, Augustus Frederic Rudolf. 1889. 'Inscribed Seal of Kumára Gupta'. Journal of the Asiatic Society of Bengal 58: 84-88.

Handa, Devendra. 1903. 'Some Problems of Ancient Indian History'. Journal of the Royal Asiatic Society 1903: 545-70.

IAR. Indian Archaeology, A Review. New Delhi: Archaeological Survey of India.

Inden, Ronald, Jonathan Walters, and Daud Ali, eds. 2000. Querying the Medieval: Texts and the History of Practices in South Asia. New York: Oxford University Press.

Jagan Nath: see Agrawal, Jagannath

Jain, Kailash Chand. 1972a. Ancient Cities and Towns of Rajasthan: A Study of Culture and Civilization. Delhi: Motilal Banarsidass.

Jain, Kailash Chand. 1972b. Malwa through the Ages: From the Earliest Time to 1305 A.D. Delhi: Motilal Banarsidass.

Jena, Siddheswar, ed. 1987. Narasimha Purana. Delhi: Nag Publishers.

Johnston, E. H., ed. 1936. The Buddhacarita. Panjab University Oriental Publications 31. Calcutta: Baptist Mission Press.

Joshi, M. C. 1983. 'Śākta-Tantrism in the Gupta Age'. In Aruna-Bhāratī. Professor A. N. Jani Felicitation Volume, edited by B. Datta, 77-81. Baroda: Oriental Institute.

Joshi, M. C. 2002. 'Historical and Iconographic Aspects of Śākta Tantrism'. In The Roots of Tantra, edited by Katherine Anne Harper and Robert L. Brown, 39-55. Albany: State University of New York Press.

Kane, Pandurang Vaman. 1949. 'Varāhamihira and Utpala: Their Works and Predecessors'. Journal of the Bombay Branch of the Royal Asiatic Society, New Series 24-25: 1-31.
Kangle, R. P., ed. 1960. The Kautịlīya Arthaśāstra. Part I, A Critical Edition with Glossary. University of Bombay Studies, Sanskrit, Prakrit and Pali 1. Bombay: University of Bombay.

Kangle, R. P., ed. 1963. The Kautịlīya Arthaśāstra. Part II, An English Translation with Critical and Explanatory Notes. University of Bombay Studies, Sanskrit, Prakrit and Pali 2. Bombay: University of Bombay.

Kano, Kazuo. 2017. 'Tathāgatagarbhaḥ Sarvasattvānāṃ - 涅槃経に おける如来蔵の 複合語解釈にかんする試論-’. Critical Review for Buddhist Studies (불교학리뷰) 22: 9-61.

Kaul Shastri, Madhusudan, ed. 1945. The Vāmakeśvarīmatam: With the Commentary of Rajjānaka Jayaratha. Srinagar: Research Department, Jammu and Kashmir Government.

Kielhorn, Lorenz Franz. 1890a. 'Die Mandasor Inschrift vom Mâlava Jahre 529 (=472 n. Chr.) und Kâlidâsa’s Ṛitusamihâra’. Nachrichten von der Königlichen Gesellschaft der Wissenschaften und der Georg-Augusts-Universität zu Göttingen (philologisch-historische Klasse) 1890: 251-53.

Kielhorn, Lorenz Franz. 1890b. 'Kanaswa Stone Inscription of Sivagana; The Malava Year 795 Expired'. The Indian Antiquary 19: 55-62.

Kielhorn, Lorenz Franz. 1891. 'Miscellanea: Corpus Inscriptionum Indicarum Vol. III'. The Indian Antiquary 20: 188-90.

Kielhorn, Lorenz Franz. 1901a. 'Aihole Inscription of Pulikesin II.; Saka-Samvat 556'. Epigraphia Indica 6: 1-12.

Kielhorn, Lorenz Franz. 1901b. 'Sarsavni Plates of Buddharaja; [Kalachuri-]Samvat 361'. Epigraphia Indica 6: 294-300.

Kishore, Naval. 1999. 'The Aulikaras of Central India: A Study'. PhD Thesis, Panjab University, Chandigarh.

Krishna Deva. 1958. 'Indragadh Inscription of Nannappa, V. S. 767'. Epigraphia Indica 32: 112-17.

Lall, Panna. 1918. The Dates of Skandagupta and His Successors. Allahabad: Reprinted from the Hindustan Review (January 1918) by $\mathrm{H}$. Liddell.

Law, Bimala Churn. 1954. Historical Geography of Ancient India. Paris: Société Asiatique de Paris.

Lienhard, Siegfried. 1984. A History of Classical Poetry: Sanskrit Pali - Prakrit. A History of Indian Literature, III/1. Wiesbaden: Harassowitz.

Lorenzen, David N. 2002. ‘Early Evidence for Tantric Religion’. In The Roots of Tantra, edited by Katherine Anne Harper and Robert L. Brown, 25-38. New York: SUNY Press.

Lorenzen, David N. 2006. Who Invented Hinduism: Essays on Religion in History. Yoda Press.

Luard, Charles Eckford. 1908. 'Gazetteer Gleanings in Central India'. The Indian Antiquary 37: 107-10.

Luard, Charles Eckford, and Dwārka Nāth Sheopuri. 1908. Gwalior State Gazetteer. Volume I. Text and Tables. The Central India State Gazetteer Series. Calcutta: Superintendent of Government Printing.

Luniya, B. N. 1954. 'Dharmrajeshwar or Dhamnar and Other Caves'. In Proceedings of the Indian History Congress. Fifteenth Session: Gwalior, 375-76. Calcutta: Indian History Congress Association.

Majumdar, Ramesh Chandra. 1954. The Classical Age. The History and Culture of the Indian People 3. Bombay: Bharatiya Vidya Bhavan.

Majumdar, Ramesh Chandra, and Anant Sadashiv Altekar, eds. 1954. The Vākāțaka-Gupta Age, circa 200-550 A.D. Reprint of first edition of 1946. Banaras: Motilal Banarsidass. 
Mankodi, Kirit. 2015. 'The Mandasor Silk Weavers' Inscription of 437 CE and Temples of the Aulikaras'. In Art, Icon and Architecture in South Asia: Essays in Honour of Dr. Devangana Desai, edited by Anila Verghese and Anna L. Dallapiccola, 305-16. New Delhi: Aryan Books International.

Meister, Michael W. 1981. 'Darrā and the Early Gupta Tradition'. In Chhavi 2: Rai Krishnadasa Felicitation Volume, edited by Anand Krishna, 192-205. Banaras: Bharat Kala Bhavan.

Meister, Michael W. 1986. 'Regional Variations in Mātṛkā Conventions'. Artibus Asiae 47 (3/4): 233-62.

Mirashi, Vasudev Vishnu. 1955. Inscriptions of the Kalachuri-Chedi Era. 2 vols. Corpus Inscriptionum Indicarum 4. Ootacamund: Government Epigraphist for India.

Mirashi, Vasudev Vishnu. 1957. 'New Light on the Ancient History of Malwa'. Indian Historical Quarterly 33: 314-20.

Mirashi, Vasudev Vishnu. 1959. 'Ujjayinī Was the Capital of the Later Aulikaras'. Indian Historical Quarterly 35: 254-58.

Mirashi, Vasudev Vishnu. 1960. Studies in Indology Vol. I. Nagpur: Vidarbha Samshodhana Mandal.

Mirashi, Vasudev Vishnu. 1961. Studies in Indology Vol. II. Nagpur: Vidarbha Samshodhana Mandal.

Mirashi, Vasudev Vishnu. 1980. 'Further Light on Yaśodharman-Viṣṇuvardhana'. In Bhārati-Bhānam (Light of Indology) Being Dr. K. V. Sarma Felicitation Volume, edited by S. Bhaskaran Nair, 405-26. Hoshiarpur: Vishveshvaranand Vishva Bandhu Institute, Panjab University.

Mirashi, Vasudev Vishnu. 1981. The History and Inscriptions of the Sātavāhanas and the Western Kshatrapas. Bombay: Maharashtra State Board for Literature and Culture.

Mirashi, Vasudev Vishnu. 1982a. Indological Research Papers, Vol. I. Nagpur: Vidarbha Samshodhan Mandal.

Mirashi, Vasudev Vishnu. 1982b. Indological Research Papers, Vol. I. Nagpur: Vidarbha Samshodhan Mandal.

Mirashi, Vasudev Vishnu. 1983. 'Mandasor Fragmentary Inscription of Kumāravarman'. Journal of the Oriental Institute, Baroda 32: $70-75$.

Mirashi, Vasudev Vishnu. 1984a. 'Risthal Stone Inscription of Prakāśadharman'. Journal of the Oriental Institute, Baroda 33: 315-24. Also published as 1984b, 27-21.

Mirashi, Vasudev Vishnu. 1984b. Studies in Ancient Indian History. Bombay: Maharashtra State Board for Literature and Culture.

Mirashi, Vasudev Vishnu. 1986. 'The Successors of Yaśodharman-Vishnuvardhana in Central India'. Rtam. Journal of Akhila Bharatiya Sanskrit Parishad 16-18: 201-3.

Mitra, Debala. 1971. Buddhist Monuments. Calcutta: Sahitya Samsad.

Monier-Williams, Monier. 1899. A Sanskrit-English Dictionary Etymologically and Philologically Arranged with Special Reference to Cognate Indo-European Languages. Oxford: Clarendon Press.

Ojha, Gaurishankar Hirachand. 1916. Annual Report on the Working of the Rajputana Museum, Ajmer, for the Year Ending 31st March 1916. Calcutta: Government of India, Central Publication Branch.

Ojha, Gaurishankar Hirachand. 1930. Annual Report on the Working of the Rajputana Museum, Ajmer, for the Year Ending 31st March 1930. Calcutta: Government of India, Central Publication Branch.

Ojha, Gaurishankar Hirachand. 1959. भारतीय प्राचीन लिपिमाला. The Palaeography of India. 3rd ed. Delhi: Munshiram Manoharlal.
Ojha, N. K. 2001. The Aulikaras of Central India: History and Inscriptions. Arun Publishing House.

Olivelle, Patrick. 2013. King, Governance, and Law in Ancient India: Kauțilya's Arthaśāstra. Oxford, New York: Oxford University Press.

Pandey, Kailash Chandra. 1988. 'नीमच तहसील का पुरातत्व'. In स्वर्गीय श्री सीताराम जाजू स्मृति-ग्रंथ, edited by Shivnarayan Gaur, 55-90. Neemuch: Seva Samanvay Samiti.

Pathak, Kashinath Babu. 1908a. 'Abhona Plates of Sankaragana. Kalachuri Samvat 347'. Epigraphia Indica 9: 296-300.

Pathak, Kashinath Babu. 1908b. 'Nripatunga and the Authorship of the Kavirâjamârga (A Reply to Dr. Fleet.)'. Journal of the Bombay Branch of the Royal Asiatic Society 22: 81-115.

Peterson, Peter. 1885. 'An Inscription from Kotah'. Journal of the Bombay Branch of the Royal Asiatic Society 16: 378-89.

Pingree, David Edwin. 1981. Jyotihśāastra: Astral and Mathematical Literature. A History of Indian Literature, vol. VI fasc. 4. Wiesbaden: Otto Harrassowitz.

Pischel, Richard. 1900. Grammatik Der Prakrit Sprachen. Strassburg: Karl J. Trübner.

Pischel, Richard. 1957. Comparative Grammar of the Prākrit Languages. Translated by Subhadra Jhā. Varanasi: Motilal Banarsidass.

Pisharoti, K. Rama. 1936. 'Vatsabhatti’s Prasasti - A Fresh Study'. In Dr. S. Krishnaswami Aiyangar Commemoration Volume, edited by V. Rangacharya, C. S. Srinivasachari, and V. R. Ramachandra Dikshitar, 69-73. Madras: G. S. Press.

PRASW. Progress Report of the Archaeological Survey of India, Western Circle.

Prinsep, James. 1838. 'Lithographs and Translations of Inscriptions Taken in Ectype by Captain T. S. Burt, Engineers: And of One, from Ghosi Taken by Captain A. Cunningham, of the Same Corps.' Journal of the Asiatic Society of Bengal 7: 629-36.

Raddi Shastri, Rangacharya. 1938. Kāvyādarśa of Daṇ̣̂in. Government Oriental Series, A.4. Poona: Bhandarkar Oriental Research Institute.

Raghavan, V. 1979. Festivals, Sports and Pastimes of India. B. J. Institute of Learning and Research: Ahmedabad.

Ramesh, K. V. 1985. 'Recent Discoveries and Research Methods in the Field of South Asian Epigraphy'. In Indus Valley to Mekong Delta: Explorations in Epigraphy, edited by Noboru Karashima, 1-32. Madras: New Era Publications.

Ramesh, K. V., and S. P. Tewari. 1983. 'Risthal Inscription of Aulikara Prakasadharmma, [Vikrama] Year 572'. Journal of the Epigraphical Society of India (Bharatiya Purabhilekha Patrika) 10: 96-103.

Sadhu Ram. 1957. 'A New Pillar Inscription from Mandasor'. Indian Historical Quarterly 33: 62-64.

Salomon, Richard. 1989. 'New Inscriptional Evidence for the History of the Aulikaras of Mandasor'. Indo-Iranian Journal 32 (1): 1-36.

Salomon, Richard. 1998. Indian Epigraphy: A Guide to the Study of Inscriptions in Sanskrit, Prakrit, and the Other Indo-Aryan Languages. New York, Oxford: Oxford University Press.

Sankalia, H. D., and M. G. Dikshit. 1948. 'A Unique VI Century Inscribed Sati Stele: From Sangsi, Kolhapur State'. Bulletin of the Deccan College Research Institute 9: 161-66.

Sastri, Hirananda. 1918. 'Haraha Inscription of the Reign of Isanavarman: [Vikrama Samvat] 611'. Epigraphia Indica 14: 110-20.

Sastri, S. N. Majumdar. 1921. 'Remarks on Mr. Bhide's Paper on the Gangdhar Inscription'. Journal of the Bihar and Orissa Research Society 7: 35 . 
Schastok, Sara L. 1985. The Śämalājī Sculptures and 6th Century Art in Western India. Studies in South Asian Culture 11. Leiden: Brill.

Senart, E. 1906. 'The Inscriptions in the Caves at Nasik'. Epigraphia Indica 8: 59-96.

Shah, Kirit K. 1993. 'The Silk-Weavers of Mandsaur in a Sociological Perspective'. Journal of the Asiatic Society of Bombay, New Series 67-68: 219-26.

Shah, Kirit K., and Kailash Chandra Pandey. 1989. 'Proud Possessions of Mandsaur Museum'. In Ajaya-Sri. Recent Studies in Indology. Prof. Ajay Mitra Shastri Felicitation Volume, edited by Devendra Handa, 437-79. Delhi: Sundeep Prakashan.

Sharma, Dasharatha. 1937. 'The Mandasore Inscription of the Silk-Weavers' Guild'. Indian Culture 3: 379-81.

Sharma, Dasharatha. 1939. 'Vatsabhațti’s Praśasti'. Indian Culture 6: 110 .

Sharma, Dasharatha. 1943. 'Yaśodharman or Yaśovarman'. Journal of the Bihar and Orissa Research Society 29: 127-28.

Sharma, Mathuralal. 2008. कोटा राज्य का इतिहास. Edited by Jagat Narayan. 2nd ed. 2 vols. Jodhpur: Rajasthani Granthagar.

Sharma, R. K., and Om Prakash Misra. 2003. Archaeological Excavations in Central India: Madhya Pradesh and Chhattisgarh. New Delhi: Mittal Publications.

Sharma, Rama Nath. 2002-03. The Așțādhyāyī of Pāṇini. 2nd ed. 6 vols. New Delhi: Munshiram Manoharlal.

Shastri, Ajay Mitra. 1989. 'Dravyavardhana of Avanti, Royal Patron of Varahamihira'. In Prācī-Prabhā: Perspectives in Indology: Essays in Honour of Professor B.N. Mukherjee, edited by Dipak Chandra Bhattacharyya and Devendra Handa, 163-75. New Delhi: Harman Publishing House.

Shastri, Ajay Mitra. 1990. “'Overlord” of the Early Maitrakas'. Journal of the Epigraphical Society of India (Bharatiya Purabhilekha Patrika) 16: 8-13.

Shastri, Ajay Mitra. 1991. Varāhamihira and His Times. Jodhpur: Kusumanjali Prakashan.

Shastri, Haraprasad. 1913. 'King Chandra of the Meharauli Iron Pillar Inscription'. The Indian Antiquary 42: 217-19.

Shastri, Haraprasad. 1914. 'Mandasor Inscription of the Time of Naravarman; The Malava Year 461'. Epigraphia Indica 12: 315-21.

Shastri, Haraprasad. 1915. 'The Susunia Rock Inscription of Chandravarman'. Epigraphia Indica 13: 133.

Shembavnekar, K. M. 1931. 'A Puzzle in Indian Epigraphy'. Journal of Indian History 10: 143-55.

Shrotriya, Alok. 2005. 'New Inscriptions Found from Eran'. Kala Vaibhav, Journal of Indira Kala and Sangeet University, Khairagarh 14: 47-51.

Sinh, Mahendra. 1978. 'Excavations Place Mandsaur Town in Madhya Pradesh on the International Map'. India Today, 15 July 1978. https://www.indiatoday.in/magazine/heritage/ story/19780715-excavations-place-mandsaur-town-in-madhyapradesh-on-the-international-map-818470-2015-01-28.

Sircar, Dines Chandra. 1950. 'Sumandala Plates of the Time of Prithivivigraha-Bhattaraka: Gupta Year 250'. Epigraphia Indica 28: 79-85.

Sircar, Dines Chandra. 1954a. 'Spread of the Malava Era'. In Proceedings of the Indian History Congress. Fifteenth Session: Gwalior, 371-74. Calcutta: Indian History Congress Association.

Sircar, Dines Chandra. 1954b. 'Two Inscriptions of Gauri'. Epigraphia Indica 30: 120-32.
Sircar, Dines Chandra. 1959. 'Capital of the Later Aulikaras'. Indian Historical Quarterly 35: 73-75.

Sircar, Dines Chandra. 1960a. 'Epigraphical Notes 2. Capital of the Later Aulikaras'. The Indian Antiquary 36: 192-96.

Sircar, Dines Chandra. 1960b. 'Note on Mandasor Inscription of Gauri'. Epigraphia Indica 33: 205-8.

Sircar, Dines Chandra. 1965a. Indian Epigraphy. Delhi: Motilal Banarsidass.

Sircar, Dines Chandra. 1965b. Select Inscriptions Bearing on Indian History and Civilization. Volume I: From the Sixth Century B.C. to the Sixth Century A.D. (Second Edition). 2nd ed. Calcutta: University of Calcutta.

Sircar, Dines Chandra. 1966. Indian Epigraphical Glossary. Delhi: Motilal Banarsidass.

Sircar, Dines Chandra. 1967. Cosmography and Geography in Early Indian Literature. Calcutta: Indian Studies: Past \& Present.

Sircar, Dines Chandra. 1984a. 'Inscription of Aulikara Prakāśadharman of Daśapura, 512 A.D.' Journal of the Asiatic Society (Calcutta) 26: Communications 13-15.

Sircar, Dines Chandra. 1984b. 'King Kumāravarman of Daśapura’. In Amrtadhārā. Professor R. N. Dandekar Felicitation Volume, edited by S. D. Joshi, 391-94. Delhi: Ajanta Publications.

Sircar, Dines Chandra. 1984c. 'Risthal Inscription of Aulikara Prakāśadharman, Year 570 (512 A.D.)'. Journal of Ancient Indian History 14: 168-80.

Sircar, Dines Chandra, and Govind Swamirao Gai. 1961. 'Fragmentary Inscriptions from Chitorgarh'. Epigraphia Indica 34: 53-58.

Somani, Ram Vallabh. 1976. History of Mewar [From Earliest Times to 1751 A.D.J. Gangapur: Shantidevi Mateshwari Publications.

Speijer, Jacob Samuel. 1886. Sanskrit Syntax. Reprinted by Motilal Banarsidass, Delhi, 1973. Leiden.

Sullivan, Bruce M. 2007. 'Tantroid Phenomena in Early Indic Literature: An Essay in Honor of Jim Sanford'. Pacific World: Journal of the Institute of Buddhist Studies 8: 9-21.

Talbot, Cynthia. 2001. Precolonial India in Practice: Society, Region, and Identity in Medieval Andhra. Oxford, New York: Oxford University Press.

Tiwari, Jagdish Narain. 1985. Goddess Cults in Ancient India: With Special Reference to the First Seven Centuries A.D. Delhi: Sundeep Prakashan.

Tripāțhī, Avadh Vihārī. 1968. Bṛhatsaṃhitā by Varāhamihirācārya with the Commentary of Bhațtotpala. Sarasvati Bhavan Granthamala 97. Vārāṇasī: Sampūrṇānanda Saṃskṛta Viśvavidyālaya.

Tripathi, Jitendra Datt. 1996. 'Rock-Shelter Paintings of Narsinghgarh'. In Recent Perspectives on Prehistoric Art in India and Allied Subjects (Essays in Honour of Dr. Shyam Kumar Pandey), edited by R. K. Sharma and K. K. Tripathi, 139-42. New Delhi: Aryan Books International.

Tripathi, Jitendra Datt. 1997. 'नरसिंहगढ़ की शैलकला में बौद्धधर्म, Buddhism in Rock Art of Narsinghgarh'. Purakala (Journal of The Rock Art Society of India) 8: 61-65.

Trivedi, Chandra Bhushan. 1979. दशपुर. Bhopal: Madhya Pradesh Hindi Granth Akademi.

Trivedi, Harihar Vitthal. 1956. 'A New Mandasor Stone Inscription'. In Proceedings of the Indian History Congress. Seventeenth Session: Ahmedabad, by Indian History Congress, 94-97. Patna: Indian History Congress Association. 
Trivedi, Harihar Vitthal. ed. 2001. Epigraphs of Madhya Pradesh. New Delhi: Director General, Archaeological Survey of India.

Tsukamoto, Keisho. 1996. A Comprehensive Study of the Indian Buddhist Inscriptions. Part I. Text, Notes and Japanese Translation. Kyoto: Heirakuji-Shoten.

Vaidya, Parashuram Lakshman. 1969. The Harivamśa, being the Khila or Supplement to the Mahābhärata. Volume I (Critical Text). Poona: Bhandarkar Oriental Research Institute.

Vaidya, Parashuram Lakshman. 1971. The Harivamśa, being the Khila or Supplement to the Mahābhärata. Volume II (Appendices). Poona: Bhandarkar Oriental Research Institute.

Vashistha, Radha Krishna. 1995. Art and Artists of Rajasthan (A Study on the Art \& Artists of Mewar with Reference to Western Indian School of Painting). Abhinav Publications.

Vasu, Nagēndranātha. 1895. 'Susuniā Rock Inscription of Candra-Varman'. Proceedings of the Asiatic Society of Bengal 1895: $177-80$.

Venkataramayya, M. 1953. 'The Ancient Mālavas: Some New Royal Names'. Indian Historical Quarterly 29: 80-83.

Wakankar, Vishnu Shridhar. 1981. 'औलिकर वंश के इतिहास पर नया प्रकाश'. In Malwa Through the Ages (Papers of the Seminar Held at Indore Museum on 7, 8 and 9 February, 1981), edited by Maheśvarī Dayāl Khare, 278-79. Bhopal: Directorate of Archaeology \& Museums Madhya Pradesh.

Wakankar, Vishnu Shridhar. 2002. भारतीय अभिलेख. Edited by Jagan Nath Dube and Bhagvati Lal Rajpurohit. Ujjain: Wakankar Shodh Sansthan.
Wakankar, Vishnu Shridhar, and Bhagvati Lal Rajpurohit. 1984. ‘दाशेरक प्रदेश के औलिकर'. Preraṇā, Journal of the Government College, Mandsaur 3: 11-24.

Warder, Anthony Kennedy. 1983. Indian Kāvya Literature Volume Four: The Ways of Originality (Bāna to Dāmodaragupta). Delhi: Motilal Banarsidass.

White, David Gordon. 2003. Kiss of the Yogini: 'Tantric Sex' in Its South Asian Contexts. University of Chicago Press.

Williams, Joanna. 1972. 'The Sculpture of Mandasor'. Archives of Asian Art 26: 50-66.

Williams, Joanna. 2004. 'On the Edge of What? Reconsidering the Place of Mandasor in the Fifth and Sixth Centuries'. In The Vākattaka Heritage : Indian Culture at the Crossroads, edited by Hans T. Bakker, 133-41. Groningen: Egbert Forsten.

Willis, Michael. 1996. Inscriptions of Gopaksetra: Materials for the History of Central India. London: British Museum Press.

Willis, Michael. 2005. 'Later Gupta History: Inscriptions, Coins and Historical Ideology'. Journal of the Royal Asiatic Society 15 (2): 131-50.

Willis, Michael. 2009. The Archaeology of Hindu Ritual: Temples and the Establishment of the Gods. New York: Cambridge University Press.

Yokochi, Yuko. 2004. 'The Rise of the Warrior Goddess in Ancient India: A Study of the Myth Cycle of Kauśikī-Vindhyavāsinī in the Skandapurāṇa'. PhD Thesis, Groningen: Rijksuniversiteit. 
